\title{
HVMANITAS
}

\section{Bocage: retratos, fantasmas, (des)encantos}

Autor(es): $\quad$ Carvalho, Teresa Duarte

Publicado por: Faculdade de Letras da Universidade de Coimbra, Instituto de Estudos

URL

persistente: URI:http://hdl.handle.net/10316.2/8522

DOI: $\quad$ DOI:http://dx.doi.org/10.14195/2183-1718_62_15

Accessed : $\quad$ 26-Apr-2023 15:00:50

A navegação consulta e descarregamento dos títulos inseridos nas Bibliotecas Digitais UC Digitalis, UC Pombalina e UC Impactum, pressupõem a aceitação plena e sem reservas dos Termos e Condições de Uso destas Bibliotecas Digitais, disponíveis em https://digitalis.uc.pt/pt-pt/termos.

Conforme exposto nos referidos Termos e Condições de Uso, o descarregamento de títulos de acesso restrito requer uma licença válida de autorização devendo o utilizador aceder ao(s) documento(s) a partir de um endereço de IP da instituição detentora da supramencionada licença.

Ao utilizador é apenas permitido o descarregamento para uso pessoal, pelo que o emprego do(s) título(s) descarregado(s) para outro fim, designadamente comercial, carece de autorização do respetivo autor ou editor da obra.

Na medida em que todas as obras da UC Digitalis se encontram protegidas pelo Código do Direito de Autor e Direitos Conexos e demais legislação aplicável, toda a cópia, parcial ou total, deste documento, nos casos em que é legalmente admitida, deverá conter ou fazer-se acompanhar por este aviso. 
humanitas

Vol. LXII

2010 


\title{
BOCAGE: \\ RETRATOS, FANTASMAS, (DES)ENCANTOS
}

\author{
Teresa Duarte Carvalho \\ Universidade de Coimbra \\ teresa.duarte.carvalho@gmail.com
}

\begin{abstract}
Resumo
Bocage foi um dos mais atormentados poetas da literatura portuguesa. Aqui se procura reflectir sobre "tormentos íntimos" que se plasticizam e adquirem, frequentes vezes, a figuração de um fantasma: do ciúme ao desamor, da glória à morte, do Fado à sombra tutelar de Camões (benigno fantasma-émulo). $\mathrm{O}$ objectivo é fazer aparecer um retrato que extravasa das molduras do mundo clássico e daquelas que a si mesmo o poeta desejaria impor.

Palavras-chave: retrato, fantasmas, imortalidade literária, épica, Camões.
\end{abstract}

\begin{abstract}
Bocage was one of the most tormented poets of Portuguese literature. This paper tries to reflect on "inner torments" that often take the form of a ghost: from jealousy to lack of love, from glory to death, from Fado to the protective shadow of Camões. The aim is to bring up a picture that goes beyond the frames of the classical world and those that the poet would like to impose to himself.

Key-words: picture, ghosts, epic, literary immortality, Camões.

Não tremo de que os séculos me ultrajem:

Lá (mercê do pincel, mercê do canto)

Meu nome viverá, e a minha imagem.
\end{abstract}

Bocage

A erosão do Tempo conduz à morte. $\mathrm{O}$ retrato realiza, pelo seu poder mágico, uma luta contra a morte: ele traz, na ilusão dos volumes, nas 
sombras do rosto, nos contrastes da alma, na luz pessoal e nos seus sinais, dispersos pelos contornos, um tempo que sobrevive ao Tempo. A morte pode transformar-se, assim, numa cortina para além da qual os vivos do passado continuam a viver no presente.

Manuel Maria Barbosa du Bocage parece ter acreditado, como poucos, na possibilidade de atravessar essa cortina. Os versos em epígrafe ${ }^{1}$, dirigidos pelo poeta a um membro da maçonaria que havia composto um soneto na presença do "retrato do Senhor Bocage, que muito [o] enterneceu", são disso um óbvio sinal. Com menor clareza, mas, ainda assim, suficiente para o leitor atento, se apresentam algumas composições em que a confiança no talento próprio e na imortalidade poética é notória. Refiro-me, concretamente, quer às composições em que, de forma directa, se dirige ao leitor vindouro ("Incultas produções da mocidade/ Exponho a vossos olhos, ó leitores" - soneto 5), quer àquelas que o pressupõem ("Quer tristes, quer ditosos amadores,/ Hão-de falar de mim com dor e espanto" - p. 69). E muitas foram as vezes em que se lhe dirigiu: para fazer coincidir alguma produção poética com a "voz da dependência", a que o obrigara a vida instável; para fundamentar certa falta de melodia, pois, em princípio, "não pode cantar com melodia/ Um peito, de gemer cansado e rouco" (soneto 6).

A verdade é que, muito embora Bocage parecesse acreditar que a sua imagem literária reunia atributos suficientes para viver depois da morte - e estava certo -, uma leitura de superfície, quer da parcela mais conhecida da sua obra poética - os Sonetos, modalidade em que se revela dos mais perfeitos cultores -, quer de outros pelouros menos conhecidos da sua escrita, como as Cantatas, as Epístolas, as Odes ou os Idílios, revelará, desde logo, uma tensão dialéctica entre a memória e o esquecimento, a traduzir o receio de ficar aquém do limiar da eternidade que tanto o atraía. Com efeito, de um lado, surge-nos um profuso leque de expressões que aponta claramente no sentido da imortalidade, a que aspira toda a grande criação literária: "perpétua fama", "grau sublime", "nome permanente", "padrões e estátuas", "véu da eternidade", "posteridade", "imortal memória" e até um "Letes preguiçoso"; do outro, as formas do apagamento e da morte: o

1 Bocage (2004-2005), Obra Completa de Bocage, vol. I - Sonetos, vol. II Cantatas, Canções, Idílios, Epístolas, Odes e Cantos, vol. VII-Poesias Eróticas, Burlescas e Satíricas in Daniel Pires (ed.). Porto, Edições Caixotim. Todas as citações da poesia de Bocage se reportam a esta edição. Por comodidade de leitura, as citações são localizadas no corpo do texto. Indicar-se-á, para os sonetos, o respectivo número; no caso das outras modalidades poéticas, o número da página correspondente. 
esquecimento, "negro" e "mudo"; o Tempo, que "gastará, que tudo gasta", como faz questão de sublinhar num idílio; os próprios "letreiros da Morte! Oh lei do Fado!/ É verdade, é verdade: acaba tudo" (soneto 368).

A complexa personalidade poética de Bocage permitiu que, ao longo do tempo, dele se tivessem traçado múltiplos retratos. Começo justamente por aquele que, sendo falso, nunca é demais apresentar, para pôr de lado ou destruir - retrato pintado com tintas malévolas de gosto plebeu, que lhe mancharam a imagem e que sucessivas gerações se habituaram a fixar na parede lisa da comodidade. Nele sobressaem, mais que os olhos azuis ou o "nariz alto no meio e não pequeno" (soneto 1), uns lábios finos, pelo riso nunca unidos, donde brota um anedotário sem fim que não deixa fissura para a grandeza do seu amplo universo poético, tão marcado pelo lirismo. Sobre este retrato (que, decerto, poria rubras as magras maçãs do rosto do poeta sadino) não luz qualquer talento - traço de que se serviu, com acerto, para a si mesmo se retratar.

Perante o perfil desenhado, Bocage repetiria talvez - pudesse ele -, a pergunta que, num soneto, a si próprio fizera, ao ver-se envolvido nos braços de uma dama venal: "Céus! Quem me reduziu a tal baixeza?" (soneto 117). Dir-se-ia que foi a sua própria fama, mais difundida que a obra - excessiva fama que, de "clima em clima", nas suas próprias palavras, bebidas em Ovídio, "por cem bocas, alígera, semeia" (p. 307).

Houve quem, optando pela linha satírica, preferisse retratá-lo de corpo inteiro, com um pé mergulhado nos botequins das horas tardias da improvisação repentista e maldizente, outro no lodo, a que conduziu a baixa boémia. Na mesma linha, outros, mais fixados no rosto (que no retrato anterior, entretanto, se afundava), desalinharam-lhe irremediavelmente a cabeleira, carregaram demais no azul revolto dos olhos, para os fazer sair das órbitas, esquecidos dos sombreados, das horas de solidão amargamente vividas na residência fixa que a Inquisição por duas vezes lhe impôs (das poucas que teve), da entrega ao trabalho disciplinado. Há perfis cujo desenho não se coaduna com suposições apressadas e que exigem o domínio do claro-escuro: Bocage não foi apenas o boémio improvisador, foi também o burilador dos seus versos, o estudioso da tradição clássica ${ }^{2}$, o homem de vasta cultura humanística, tão presente na sua obra, o tradutor elogiado, até por Garrett. Com fundada razão, afirmou Hernâni Cidade que ele soube

2 Vide, sobre esta faceta, M. H. Rocha Pereira (1967-1968), "Bocage e o legado clássico", Humanitas 19-20: 267-302. 
"erguer do lodo os pés jamais nele presos - posto que, mais de uma vez, fundamente mergulhados"3.

Outros, ainda, pelo contrário, rejeitando a "quinzena e calção muito coçado, sapatos cambados de fivela barata"4, numa espécie de recusa de traços que o poeta assume nos seus versos, quiseram dar-lhe ares de aristocrata, não entendendo que - observou-o Sebastião da Gama - "sem a estúrdia, sem a vadiagem, sem a desgraça, nunca Bocage, sequer, teria sido grande!"5.

É também muito frequente vê-lo, sobretudo nos escritos dos que lhe estudaram a obra, mas também em antigos manuais escolares - e entramos no domínio daquele retrato que, de um modo geral, transpõe o âmbito da biografia romanceada para se centrar na obra - ora sobre prados vestidos de boninas, entre Zéfiros e Marílias, com Tejo sorridente ao fundo ${ }^{6}$, ora entre os escombros da Arcádia (espaço demasiado acanhado para o seu estro), fascinado por uma natureza selvagem - imagem que pinta em relevo a antecipação romântica do poeta. É bem verdade que a complexidade poética de Bocage não se contém na rigidez dos moldes clássicos e não fica completo com as cores pré-românticas da noite ${ }^{7}$. Bocage extravasa das molduras. E não apenas das do mundo clássico, no seu tempo em agonia histórico-cultural. Na efervescência dos seus sentimentos incontidos, extravasou também das molduras que a si mesmo desejaria impor.

Outros retratos poderiam perfilar-se ainda. Por exemplo, um Bocage, qual Narciso, enamorado, não da sua imagem física, que lhe mereceu um olhar irónico, mas dos seus próprios versos - aplaudidos em adulação continuada na atmosfera do botequim e do café -, sobrepondo o desejo de vencer a morte às regras de modéstia exterior, sobretudo quando o elogio chegava por voz autorizada: "Zoilos, estremecei, rugi, mordei-vos!/ Filinto, o grão cantor, prezou meus versos. [...] O imortal corifeu dos cisnes lusos/ $\mathrm{Na}$ voz da lira eterna alçou meu nome. [...] Zoilos, tremei! Posteridade, és

3 Cidade, H. (1965), no prefácio à Homenagem Nacional a Bocage no II Centenário do seu Nascimento - Conferências evocativas do poeta, proferidas nos Paços do concelho de Setúbal, Edição da Junta Distrital de Setúbal: 19.

4 Cidade, H. 1980: 25.

5 1965: 88.

6 Veja-se, a título de exemplo, o soneto 21: "Já se afastou de nós o Inverno agreste" e o célebre soneto 33: "Olha, Marília, as flautas dos pastores".

7 Vide Mourão-Ferreira, D. (1966), "O drama de Bocage": Hospital das Letras. Lisboa, Guimarães Editores: 57-62. 
minha!". A esta imagem, porém, facilmente se pode contrapor a imagem de um Bocage que, ao cotejar-se com a figura de Camões, seu par na arte do soneto, não ousa ir além dos paralelismos da (des)ventura: "Camões, grande Camões, quão semelhante/ Acho teu Fado ao meu, quando os cotejo! [...] mas... oh tristeza!/ Se te imito nos transes da Ventura, não te imito nos dons da Natureza" (soneto 186). À explosão de egoísmo vaidoso é necessário juntar matizes de sensatez e comedimento humilde, sob pena de lhe deformarmos o rosto.

A uma distância de 245 anos passados sobre a data do seu nascimento, muitos retratos foram já apresentados. Há, porém, um retrato poético de Bocage que, não sendo desconhecido, talvez não tenha sido ainda suficientemente ampliado e em cujos recantos obscurecidos, quer por uma popularidade que tantas vezes lhe nega o lugar que lhe compete nas letras portuguesas, quer pelo próprio descaso da moderna crítica literária, salvo honrosas excepções, convém penetrar: o retrato de um Bocage atormentado ${ }^{8}$.

De génio instável e mente abstracta, Bocage foi, com efeito, um dos mais atormentados poetas da literatura portuguesa: "Ânsias terríveis, íntimos tormentos,/ Negras imagens, hórridas lembranças,/ Amargosas, mortais desconfianças,/ Deixai-me sossegar alguns momentos" (soneto 138). O tormento interior e a ânsia violenta (um sofrimento brusco, por vezes, sem razão aparente: "Ó Céus! Que sinto n'alma! Que tormento!/ Que repentino frenesi me anseia!" - soneto 75), pertencem à problemática família das grandes designações do mal de viver, que o poeta define como um "veneno/ a ferver de veia em veia", a consumir-lhe ininterruptamente a vida e a desfazer-lhe o alento.

Atormentou-o o Fado que, nefastamente insinuado logo à nascença, nunca deixou de o perseguir; a ausência do "pátrio Sado", ditada por conveniências familiares e sonhos vãos; a incerteza - "Oh que infernal tormento o da incerteza!" - soneto 133 (que decorre, desde logo, do "choque do mundo clássico, que serenamente repousa no século XVII, com o mundo romântico, que se agitará no seguinte" ${ }^{\text {") }}$; certas visões da amada, nos seus múltiplos nomes, que o não deixavam sossegar; estranhas e pesadas vozes, em que se sente o misterioso arrepio dos lugares consagrados aos deuses, que anunciavam extorquir-lhe a glória ou a liberdade; as sombras da clausura; a morte, na sua distância insondável ou na certeza da sua proximidade; enfim,

\footnotetext{
8 Cf. Prado Coelho 1966.

9 Cidade, H. 1980: 19.
} 
"ânsias terríveis, íntimos tormentos", que no universo poético bocagiano se plasticizam e adquirem, com larga frequência, a figuração de um fantasma.

Mas, se a série de tormentos enumerados - chamar-lhe-ia Bocage "chusma bisonha" - parece rodar-lhe em torno, numa espécie de dança lúgubre que arrepia e seduz, outros, como a sombra tutelar de Camões fantasma-émulo - que o acompanha na viagem ao Oriente ${ }^{10}$, apresentam-se como espíritos de influência benigna e inspiradora, sempre a pairar sobre o seu espaço poético.

Outros, de talhe bem diferente, mas não menos medonhos, são os fantasmas ou, melhor, as sombras de assustar geradas pela tradição, pela hipocrisia clerical e por uma moral sexual contrária à razão e à natureza humana, para depois agitar perante o rosto apavorado das gentes do século XVIII: o espectro do Inferno e a sua "torrente de horrores", aquele grande fantasma a que o poeta deu o nome de "Pavorosa ilusão da Eternidade,/ Terror dos vivos, cárcere dos mortos", que pinta na "Epístola a Marília". Ao contrário de outros, não o assombram estas criações cheias de indignação irada, sedentas de sacrifícios bárbaros, e que o poeta tenta, nos seus versos, reduzir a pó (p. 3):

Perpétua escuridão, perpétua chama,

Incompatíveis produções do engano,

Do sempiterno horror terrível quadro

(Só terrível aos olhos da ignorância).

Não, não me assombram tuas negras cores,

Dos homens o pincel e a mão conheço.

Mal acabara de nascer, diz-nos numa ode o poeta sadino, logo foi visitado por seres nefandos, num prenúncio de vida aziaga (p. 291):

A luz primeira, que meus olhos viram,

Foi de fantasmas infernais toldada

Eles o berço me embalaram, dando

Hórridos gritos.

As torvas Parcas me fadaram logo,

Negros agouros sobre mim caíram,

E de meu lado com terror voaram

Júbilo e riso.

10 Cf. Nemésio 1972: 12-13. 
Bocage familiarizara-se com o afago da morte, que cedo se substituiu ao da mãe, que perdeu aos dez anos. Quando, "das faixas infantis despido apenas" (soneto 82), abria os olhos para a poesia, já aqueles seres fantasmáticos o habitavam. A sua lira frágil não tinha nem os poderes mágicos das ervas de Medeia, feiticeira mitológica cuja acção cruel conhece desenvolvimentos pela pena do poeta, nem os da lira de Orfeu, poeta lendário que invocou, para que os pudesse enfeitiçar ou dominar. Assim, "que havia de fazer? $\mathrm{Ce}[\mathrm{deu}]$ ao Fado" (soneto 82) e, ao invés de os afugentar (como ousou fazer, por exemplo, com a visão medonha que a Igreja do seu tempo fazia de Deus ${ }^{11}$ ), com eles se identificou, numa sensibilidade exacerbada pelo sofrimento, a que depois se chamou pré-romântica ${ }^{12}$ : "E vós, ó cortesãos da escuridade,/ Fantasmas vagos, mochos piadores,/ Inimigos como eu da claridade!// Em bando acudi aos meus clamores:/ Quero a vossa medonha sociedade,/ Quero fartar meu coração de horrores! (soneto 48).

De regime ansiosamente nocturno, muito embora a claridade matinal não esteja arredada e nela existam "benignas manhãs", de serenidade e harmonia marcadamente clássicas, é a página poética de Bocage caminho de fantasmas, mil vezes percorrido. Aprenderam a mover-se na insónia da noite e a suspenderem-se em medos muitos. São entes que se insinuam por entre as dobras da noite, na intimidade do seu quarto, um "deserto e lúgubre aposento,/ que semimorta luz mais afeava" (soneto 27) ou no silêncio absoluto de uma natureza de horror, quando todos dormem, excepto ele. Do ponto de vista do discurso poético, os entes nocturnos, que estabelecem com a morte, almejada e sempre temida, um vínculo estreito, fazem-se anunciar, nas suas composições mais características, ora por formas verbais dinâmicas alusivas ao seu aparecimento surpreendente (aparecer, surgir, afigurar-se, assomar), ora pelo advérbio "eis" que, exprimindo um sintomático movimento do interior para o exterior, privilegia a dominante do olhar, logo convocado. A obscuridade da linguagem poética adequa-se na perfeição ao confronto

11 A reacção contra essa visão ficou exemplarmente expressa nestes versos: "Oh almas sem acordo, e sem brandura,/ Falsos órgãos do Eterno! Ah!... Profanai-o,/ Dando-lhe condição tirana e dura!/ Trovejai, que eu não tremo, e não desmaio,/ Se um deus fulmina os erros da ternura,/ Uma lágrima só lhe apaga o raio".

12 Um conjunto de características gerais é habitualmente apontado à sensibilidade romântica e pré- romântica: o gosto da solidão nocturna, do belo horrível (ambientes tenebrosos que integram uma tradição trágica e clássica dantesca, que é particularmente insistente na obra poética de Bocage), o egocentrismo, o autobiografismo. 
do "eu" com um destino que os fantasmas vão insistentemente repetindo em "decretos", sempre com novas adendas.

Em consonância com a atmosfera de morte em que surgem envolvidos, os fantasmas que o visitam, em sonhos ansiosos ou em estado de vigília, sempre em horas escuras, têm notações cromáticas denunciadoras de furor e desgraça. São feitos de negrume, tons de cinza, pálidas cores e vermelho sanguíneo, a captar a retina do leitor pela transmissão visual da agonia do próprio poeta, desesperadamente impotente para alterar o momento interminável momento - que experiencia.

Ao elemento visual vem juntar-se, por vezes sobrepor-se, o elemento auditivo: fantasmas que gritam, fantasmas que falam ao ouvido em tom ferino ou que sussurram desgraças. A proximidade ou o contacto físico ("ante mim", "ei-lo a meu lado", "junto de mim") adequa-se a uma mensagem oralmente comunicada e, de um modo geral, furtiva a metáforas ou a imagens. Uma leitura atenta das composições em que surgem estas figuras ilusórias revelará que muitos dos tormentos do poeta se apoiam sobre a experiência de um olhar "torvo", baço ${ }^{13}$, que surge como o meio privilegiado de expressão e de revelação de um estado de alma.

Emergindo sempre da noite, a morte - uma das figuras fantasmáticas mais típicas e recorrentes do universo poético bocagiano - revela-se, ora numa presença esvoaçante que estende a sua sombra obsessiva sobre os seus versos, por vezes já extenuados (“o horror da morte,/ que d'asas negras me esvoaça em torno"), ora numa presença macabra que lhe devassa o sono, sempre curto, para anunciar o fim de uma existência agónica (soneto 10):

De suspirar em vão já fatigado,

Dando trégua a meus males, eu dormia;

Eis que junto de mim sonhei que via

Da Morte o gesto lívido e mirrado.

Curva fouce no punho descarnado

Sustentava a cruel, e me dizia:

«Eu venho terminar tua agonia:

Morre, mão penes mais, ó desgraçado.

13 Este olhar turvo encontrá-lo-emos em Antero de Quental. Vide Maria Graciete Besse (1992), "A experiência do olhar desamparado: "no turbilhão", de Antero", Colóquio/ Letras 123-124: 131-134. 
O fantasma sinistro, determinado a cumprir o que anunciara, ainda chega, neste soneto, a investir sobre a sua vida, mas a possibilidade da libertação logo é contrariada por uma aparição de voz enfurecida - o Amor, funesto guardião da vida do poeta que rivaliza com o fantasma da Morte e, em tom firme, lhe diz: "Emprega noutro objecto os teus rigores,/ Que esta vida infeliz está guardada/ Para vítima só de meus furores" (soneto 10). A morte não desistirá - "teimosa fantasia" a do poeta - e há-de aparecer-lhe muitas outras vezes, "por entre os véus da noite fria", ora só, coberta com "lutuosa veste", a envolver as "alvas, mimosas carnes" (soneto 119) da bela Armia, perante o seu grito horrorizado e impotente, a repercutir até nós um pulsar alarmante, ora ladeada da Desgraça e de um rosário desfiado de males donde se ergue a misteriosa (e temida) voz da Glória, sempre a torturá-lo, como se viesse cobrar o elevado preço das muitas horas dissipadas nos botequins e no entrelaçado estreito das ruas de uma Lisboa nocturna, plena de mazelas morais: "De te honrar desisto" (soneto 123).

A lúgubre visão da morte, que em si resume quanto pavor há nas profundezas - faz notar Bocage - e de quem o poeta conhece até o "hálito infesto e ansioso", surge-lhe, uma noite, em poderosa imagem por si criada e não menos densa de emoção, "c'o Ciúme ao lado", exigindo-lhe, em brados, como num derradeiro acorde, uma decisão: "Escolhe, desgraçado,/ Queres a Morte, ou queres o Ciúme?" (soneto 74). A resposta, antecedida do tradicional suspiro, chega sem hesitações: "Antes mil mortes, mil infernos antes".

À vista destas cenas de espantar, em que sobressai, sobre um fundo de negro sólido, a espectral cor amarela, tão própria desta figura ("Tive a morte ante mim torva, amarela" - soneto 123) reage o poeta, naturalmente, como à de um fantasma: "De nocturno, horroroso pesadelo/ Fui na mente sombria atormentado:/ Inda palpito, da visão lembrado,/ Esfria o sangue, eriça-se o cabelo" (soneto 123).

É também com o coração estremecido - e com sangue frio - que, num admirável soneto, defronta a aparição do fantasma que é o próprio Fado, "Pavoroso gigante, enorme vulto:/ Tinha na mão sinistra, e quase oculto/ Volume em férrea pasta encadernado". O olhar bocagiano, participando na dialogização constante que, dando a ver o assombro, amplia o drama, e dominando a trama imagética dos versos, não contém o olhar inquiridor: "«Ah! Quem és? (lhe pergunto arrepiado)/ Mereces o meu ódio, ou o meu culto?»/ «Sou (me diz) o que em sombras te sepulto,/ Sou teu perseguidor, teu mal, teu Fado»" (soneto 370). 
O espectro perseguidor, sem se perder nas detalhadas explicações que o Fado, por definição, não pode dar, prefere apontar, para dar a ver aquela que o poeta, pelo longo convívio, há já muito conhece: "Olho rapidamente, e vejo a morte". A imagem não chega a plasticizar-se: não o permite o susto nem a contenção a que obriga a forma do soneto. Ao lado do "Fado inimigo" caminha sempre, na sua poesia, o espectro do receio - receio do destino que lhe move contínua perseguição, da morte, dos rivais, do desamor, do abandono da glória, do próprio Tempo, esse "perverso estragador da formosura", que, por uma única vez, desce dos ares em seu auxílio (soneto 139):

De emaranhadas cãs o rosto cheio,

De acaçalada foice armado o braço,

Gigântea estatura, aspecto baço,

Um velho em sonhos vi, medonho e feio

«Não tenhas, ó Mortal, de mim receio.

O Tempo sou (me disse) eu despedaço

Os colossos, os mármores desfaço,

Prostro a vaidade, a formosura afeio

«Mas sabendo a razão de teus pesares,

Pela primeira vez enternecido,

A falar-te baixei dos ténues ares».

Nem sempre, porém, são os fantasmas que vão ao encontro do olhar ansioso do poeta, em regime de súbita visitação que, diga-se, a frequência vai tornando familiar. A viva desesperação condu-lo, num célebre soneto alegórico, à casa assombrada que é, por excelência no seu universo poético, a morada do ciúme, esse "tormento abrasador" que tem como ministros um elenco fantasmático: "a Aleivosia,/ O Susto, a Morte, a Cólera, o Queixume", a convergir numa única visão de desenho confuso que há-de arrancar-lhe o grito exorcizante: "Guiou-me ao templo do letal Ciúme/ A Desesperação que em mim fervia;/ O cabelo de horror se me arrepia/ Ao recordar o formidável nume" (soneto 32).

O retrato de um Bocage atormentado por toda a sorte de fantasmas, traço a traço, vai-se esboçando, assim, nas suas feições características: olhos de justificado espanto, cabeleira eriçada, carnes arrepiadas, membros titubeantes, boca breve, ora muda de assombro, ora interrogativa, ora ainda aberta e sempre alterada pelo grito arrancado à caixa estreita e sobressaltada 
do coração. Uma moldura que se ajuste a este retrato de corpo inteiro terá de conter, por força da escura imaginação do retratado, um friso de imagens dantescas. Consentissem a sua fantasia e a própria natureza feminina, e o retrato bem podia ser outro, como parecem sugerir os seguintes versos: "Ah! Trazei-me, ilusões, a ingrata, a bela/ Pintai-me vós, ó sonhos, entre flores,/ Suspirando outra vez nos braços dela" (soneto 28).

De entre os traços gerais com que se compõe a imagem de um poeta de mente talhada para o assombro, não raro, é o olhar que sobressai, desmedidamente dilatado em espanto, quantas vezes pela aparição do rival temido. Desta aparição concorrente retém o poeta, num dos sonetos que derrama ciúme, algumas feições que a sua imaginação transfiguradora traça com linhas brutas e preenche com as cores feias que lhe convêm (soneto 111):

Audaz competidor, esse que aspira

De teus carinhos ao celeste encanto

Grosseiro e carrancudo, infunde espanto,

Da bruta estupidez nas sombras gira

Ao vê-lo assim, e ao ver minha amargura

Mal que ele a ti dirige a vista acesa,

Todos ao meu temor chamam loucura

O uso do verbo 'girar', tão adequado, nas suas linhas de irradiação semântica - rodear, rondar, circundar - ao movimento descrito pela visitação do rival na mente do poeta, se, por um lado, envolve o leitor na sua sugestão cinética, por outro, traduz a impossibilidade da apreensão, não fosse o rival um fantasma ilusório com origem em receios de traição e abandono. De um fundo rubro de suspeita e incerteza, recorta-se, não o rosto furtivo do que gira nas sombras, mas um rosto que dá ares de louco - o do próprio poeta.

Dir-se-ia que Bocage é, ele mesmo o reconhece, um infatigável fazedor de fantasmas. Pela sua imaginação desfilam visões, espectros nefandos, sombras e outras criações, perante um olhar que, recusando uma posição estática e contemplativa, prefere defrontar e inquirir. Consciente disto mesmo, estabelece um paralelismo entre a sua imaginação, sempre pronta a laborar, e uma urdidura - um íntimo bordado que lhe ocupa as noites insones e os dias inquietos: "Das sombras abrigada, a frágil teia/ Urde Aracne sagaz de canto em canto,/ Minha imaginação faz outro tanto,/ Mil tristes pensamentos forma, enleia.// Minha imaginação de algoz me serve" (soneto 147). 
A comparação soa justa. Tal como Aracne - jovem da Lídia com provas dadas na arte da tecelagem e que a deusa Atena, por despeito, transformou em aranha - também o poeta, acolhido à protecção do "domicílio da noite", fabrica, sem paragem nem repouso (ideia que a elaboração rítmica daqueles versos tão bem expressa), uma teia de "tristes pensamentos" onde acabará por se enlear.

Se a ferramenta privilegiada deste fazedor de fantasmas é o milagroso pincel que convém a um "pintor do invisível", como acertadamente lhe chamou Jacinto do Prado Coelho ${ }^{14}$, a matéria-prima é, para além das "sombras da tristeza" ou do tecido escurecido da sua vida, as linhas pressagas do Fado, os fios que as Parcas fiam - a morte, a sua própria e a da amada -, "os duros laços de um amor profano" (soneto 14) e as retorcidas linhas do ciúme. De tantos fios cruzados em fantasia teimosa, a fazer as vezes de um "algoz", não surpreende que o resultado final se apresente sob a forma de um novelo de visões donde sobressai o fantasma radioso de Eros. É a arte de fazer aparecer figuras luminosas em lugar escuro"15: "De encontradas visões na fantasia/ Baralhado tropel me cai, me ferve,/ E nesta confusão reluz Armia" (soneto 147).

Escusado será afirmar que, no espaço poético de Bocage, a fronteira entre o sonho e o real - um real turvado, fantasmagorizado - conhece, de um modo geral, limites muito ténues: "Sonho ou velo?!" (soneto 110). A interrogação exclamativa não é apenas uma forma de mostrar a hesitação: a disjunção, que, ao invés de introduzir a ideia comum de uma clara separação entre duas esferas distintas, a onírica e a real, deixa entender uma fluidez, traduz, para além da ausência óbvia de uma linha divisória, uma inquietação a oscilar entre dois pólos que divergentemente atraem, repelem, atormentam e dilaceram.

É nesta zona de indefinição, favorável ao labor da fantasia, que surgem luzentes visões amorosas que adquirem frequentes vezes nesta poesia o estatuto de um fantasma evanescente, cuja elaboração cromática estabelece com as cores da Morte, do Fado ou do Ciúme (de coloração predominantemente soturna) um aberto contraste. Os efeitos por elas produzidos no poeta reflectem-se nos "olhos pasmados" de enlevo e expressam-se normalmente na forma exclamativa, depois suspensa, e no próprio desenho estrófico do soneto 110:

14 Prado Coelho 1966.

15 Esta arte, em que Bocage é exímio, recebe, como é sabido, o nome de fantasmagoria. 
Sonho ou velo?! Que imagem luminosa,

Esclarecendo o manto à noite escura

A meus olhos pasmados se afigura,

Sopeia a tua dor, alma saudosa!

De mais vistoso objecto o Céu não goza,

A clareza do Sol não é mais pura...

Que encanto! Que esplendor! Que formosura!...

Caiu-te um astro, abóbada lustrosa!...

Esta suspensão da imagem feminina sobre um fundo difuso é insustentável e resolve-se através de um suave movimento que a aproxima do poeta que nela se fixa em dúvida delirante: "Ah! Como inclina/ a face para mim, branda, apiedada...// Refulgente visão, tu és de Ulina,/ Tu és cópia fiel da minha amada,/ Ou reflexo talvez da Luz divina". Em espanto entrecortado perante o espectáculo visionado, o discurso poético parece, assim, manipular a atenção do leitor num processo alucinatório, conduzindo-o para esse acontecimento de elaboração mental. A transparência cromática em que a própria aparição amorosa acabará necessariamente por se dissolver, sugere a irrealidade de tudo, num desfecho, por vezes plácido, a indiciar uma perda já anunciada.

Muitas são as composições da lírica bocagiana que se realizam nesta espécie de delírio ou alucinação - capaz de duplicar, distorcer, deformar, desfigurar - e que só a percepção exaltada, nos excessos sentimentais do romântico, permite. É justamente esta percepção de exuberância imaginosa, que decorre de traços da fisionomia espiritual de Bocage - sombria, "mais propens[a] ao furor do que à ternura" (soneto 1) - que permite que Marília flutue, "suspensa entre o temor, entre o desejo" (soneto 136), que Lília voe no seu pensamento, "nas asas de esperanças sequiosas" (soneto 9), ou que Armia vagueie, qual fantasma, na noite lúgubre de um sonho sinistro, conservando um "ar celeste" (soneto 119). A mesma Armia que, fazendo a transição entre a esfera onírica e a esfera do Fado, o sonhar e o velar, pondo fim ao delírio, se lhe dirige e lhe diz: "Esta que vês (me disse em tom magoado)/ É sombra vã, fantasma inanimado". Feita a revelação, chega o grito, seguido daquela que, em boa verdade, sempre se assumiu como a mais funesta visão de Bocage - a realidade: "Grito, acordo, e seguiu-se (oh duro Fado!)/ À funesta visão fatal verdade" (soneto 119). A luz do desengano irrompe, assim, ferindo a obscuridade da página poética bocagiana. 
Evanescente é, também, a imagem ilusória da alva Gertrúria, de rosto encantador, que, em sonhos gostosos, se precipita para os seus braços e se inclina para os seus lábios, ávidos de prazer. Mas a felicidade (não apenas amorosa) tem em Bocage a curta duração de um sonho bom, é efémero "prazer de um desgraçado", afirmará o lado lúcido do poeta: "Acordo, acho-te só no pensamento/ Ó destino cruel! Ó Sorte escura!” (soneto 42). E o destino é ainda mais cruel e a sorte ainda mais escura quando tudo se desfaz "no mais doce, no melhor momento", deixando o poeta enlaçado nos braços da ausência, a fazer contas de resultado inane.

Assim, àquele retrato de Bocage anteriormente esboçado, vem sobreporse agora um outro. O título, a existir, bem poderia ser o mesmo: "Retrato de Bocage atormentado". Mas agora pelo fim de uma visitação ilusória que mais não pode dar-lhe que a medida exacta da sua condição humana: testa em suores; cores macilentas recobrindo a face lívida; pupilas de azul líquido contraídas pelo desencanto e como que a prevenir, em vão, a entrada repentina da luz que acabará por feri-las outra vez; boca, ora suspensa, a aguardar ainda o beijo impossível, ora afadigada de amaldiçoar o destino; cabelo em desalinho; queixo caído no mais solitário desamparo, alma escurecida e ensimesmada - tudo enquadrado em moldura (pré) romântica.

$\mathrm{O}$ breve encontro com as aparições que Eros desmultiplica em "mil deidades", digo - com Bocage -, em "moças mil", parece, porém, apesar de todo o desencanto e crueza, quase desumana, valer a pena. Se não, porque agradeceria entusiasticamente o poeta, a um tempo, ao deus suscitador do sonho, que as possibilita, e à própria fantasia? "Bem hajas, ó Morfeu; à fantasia/ Que cena divinal me deste agora!/ Nise, qual sai da noite a grata aurora,/ Surgiu-me dentre as sombras da agonia" (soneto 24). Se não, porque recorreria aos favores do sonho? - "E vós, sonhos d'amor, trazei-me Alcina,/ Dai-me a doce visão dos seus agrados" (soneto 125). Mas talvez seja útil lembrar que quando o poeta reflecte, em jeito de balanço amoroso, sobre os fugazes afagos femininos, mesmo nos que realmente chegou a receber, o saldo é escassamente positivo: "Fiei-me nos sorrisos da Ventura,/ Em mimos feminis, como fui louco/ Vi raiar o prazer, porém tão pouco/ Momentâneo relâmpago não dura" (soneto 34).

A desproporção entre a pouca coisa que o amor se revela ser - mimos ${ }^{16}$ - e as perturbações que dele decorrem, fica expressa nesta quadra, onde se retoma o motivo da loucura, forma extrema de incoerência que impede

16 O vocábulo "mimos" percorre a obra de Bocage de forma particularmente insistente nos sonetos de carácter autobiográfico e no lirismo amoroso. 
toda a continuidade interior. Desenganado do amor e do Fado, Bocage, fantasma de si mesmo, compara-se a uma sombra triste: "No meio agora desta selva escura,/ Dentro deste penedo húmido e oco/ Pareço, até no tom lúgubre e rouco,/ Triste sombra a carpir na sepultura" (soneto 34). As suas expectativas secaram e delas fica uma raiva ineficaz contra o sem sentido de uma existência que aborrece, de uma vida assombrada de si mesma.

Nem todos os fantasmas do universo poético de Bocage são "fantasmas vagos", imagens ilusórias. Camões, seu modelo assumido, poeta que, ao invés dele próprio, viveu quase desconhecido para aparecer, depois da morte, envolto no manto da glória, cercado de uma misteriosa penumbra, própria dos mitos, adquire na sua poesia contornos próximos de um fantasma, um revenant, o que sempre regressa mas de quem, ao fim, não se conhecem senão os versos que, de resto, o poeta vivamente recomenda numa ode: "Lê Camões, Lê Camões, com ele a mente/ Fertiliza, afervora/Povoa, fortalece, apura, eleva" (p. 276). Quem quer que seguisse o conselho de Bocage, dar-se-ia conta, para além do facto de que Camões não escrevera apenas Os Lusíadas, de que as imagens cheias de cor e de aventura relatadas na sua epopeia, e que o poeta guarda ainda na retina, não tinham, no século XVIII, correspondência. Tinham adquirido novas formas, novos contornos, novas tonalidades, ao estilo da época. As façanhas grandiosas da era de Quinhentos deram lugar a saborosas aventuras de amor, muitas delas começadas no espaço do sagrado; tinham revertido os sucessos guerreiros em fortunas sem grandeza, exibidas por uma aristocracia cada vez mais arredada da vida militar. As trombetas e tambores ressoavam agora em atmosfera religiosa e o deslumbramento não era já o do Outro desconhecido, mas do Outro divino. As bandeiras de seda que Paulo da Gama desfraldara perante o olhar do Catual não tinham já pintados rostos heróicos, mas antevisões celestiais e eram agora agitadas por uma multidão de padres. Também as musas, agora fáceis e buliçosas, deixaram de ser invocadas para serem aplaudidas no ambiente sobreaquecido dos botequins, espaço onde se agitavam as novidades que vinham de fora, as ideias iluministas, os versos e os copos nunca vazios.

Quando Bocage parte, de vontade própria, em Abril de 1786, para o Oriente, em busca de um ideal que o elevasse acima da mediocridade dominante do Portugal de Setecentos e o dignificasse, leva no olhar o vulto do poeta épico, a quem parece querer seguir os passos: "Adeus: um vivo ardor de nome e fama/ A nova região me atrai, me chama. [...] Os mares vou talhar, cujos furores/ Descreve o grão Cantor, por quem de amores/ Inda as musas suspiram" (pp. 27-28). 
Mas a viagem em que se acha embarcado e que lhe permite conviver com espectros de criação camoniana, como o "sacrílego Gigante", não podia dar-lhe a glória da heróica gesta pretérita: bem sabia - e di-lo, por outras palavras, a Gertrúria na carta comovida em que dela se despede - que "é sólida ventura/ seguir de altos varões o ilustre exemplo:/ Por espinhos se vai da Glória ao templo" (p. 28). Faltava-lhe, contudo, o esforço continuado: "Tento, e desmaio ao começar a empresa" (soneto 101). E faltava-lhe também, sem dúvida, a boa estrela do latino heroísmo clássico. A esperança que o leva a perseguir o sonho da Índia, sempre com o fantasma de Camões a pairar sobre a sua mente, há-de reverter, mais tarde, em desesperança e desalento de ecos camonianos: "Não mais, Dor, Fado meu, Dor, meu costume" (soneto 131). A voz tutelar que, no seu timbre épico inconfundível, lhe avivara a consciência de "ser prole de varões assinalados" (soneto 159), ganha, na sua própria voz, já cansada e rouca, acentos de tristeza e desistência.

É bem verdade que, perante a tempestade marítima, e à semelhança do "afoito Gama", o poeta enfrenta o furor de ventos e marés, mas não é menos verdade que a Índia onde pôs o pé não estava já coberta por um véu de mistério e sedução, antes por um manto de soturna ruína que mais não pode que acabrunhar quem a pisa: "Das terras a pior tu és, ó Goa". Numa conhecida sátira implacável invoca o poeta espíritos do passado lusíada que, na sua luz espectral, aterrariam os nativos: "Lusos heróis, cadáveres cediços,/ Erguei-vos de entre o pó, sombras honradas,/ Surgi, vinde exercer as mãos mirradas/ Nestes vis, nestes cães, nestes mestiços" (soneto 195). De entre as "sombras honradas" ergue-se, a par de Homero, a "sombra do grão Camões, alta e divina" (soneto 218), que as cantou - uma presença feita de ausência que o persegue e o assombra. Elmano, seduzido, cita-lhe os versos, evoca-lhe o vulto ("Camões! grande Camões!"), deplora-lhe o destino, pendura-lhe o retrato no seu amplo espaço poético.

Camões alcançou a imortalidade ao celebrar em verso heróico a grandiosidade de feitos únicos, a cantar "o peito ilustre Lusitano". O "mísero Elmano" consumira-se - e consumara-se como poeta - a cantar "a condição do peito humano" (soneto 113), a cantar nascimentos e mortes de todos os dias: "Linda, real Maria,/ Este é o teu áureo dia"; "Quis, Marília gentil, cantar teu dia/ Teu dia grato a Amor, grato à ventura" (soneto 132); "Lília, inocente como virgem rosa/ [...] Em teu sagrado, perenal retiro/ Disponho ao som de lânguidas querelas/ A rosa, o cravo, a tulipa, o suspiro" (soneto 377); "Morreste, caro Aónio, puro Amigo" (soneto 376). 
Camões pôs diante dos olhos do leitor imagens que ele não viu com os seus e que acordam no poeta sadino um passado, tido por grande: sucessos guerreiros, errâncias de aventura, longas e atribuladas viagens, bulícios da vida do mar e de uma Lisboa onde afluíam riquezas várias. Abrindo, ao nível estético-literário, novos rumos, Bocage põe diante dos olhos de cada um de nós fantasmas que são também os nossos e a imagem tenebrosa que eles nem sempre querem ver: a nossa condição de "bicho da terra tão pequeno", quer dizer, o carácter trágico da existência humana sobre o qual Camões, por várias vezes, reflecte n' Os Lusíadas. Bocage, "sem o falso pudor das suas fraquezas e misérias" 17 cantou, não apenas as pequenas mortes, na sua circunstância, mas também a grande Morte - a dos amigos, a sua própria morte. Invocá-la, trazê-la até si, apreender-lhe as modulações da voz, os traços típicos, pintá-la - de negro e feio - era já uma forma de a esconjurar.

O doloroso convívio com o espectro desta figura, amplamente expresso nos seus versos, é tão obsessivo como a ideia da posteridade que os percorre. Mas, à hora final, os fantasmas tornam-se mais tangíveis, mais aterradores, mais temidos, sobretudo quando chegam sob a forma desgostosa da grande doença. A morte, pavorosa figura com quem tantas vezes privara, não é já visão imaginada, familiar, fantasma vago, mas mergulho na escuridão: "Já Bocage não sou!...À cova escura/ Meu estro vai parar desfeito em vento" (soneto 8). Estes versos não deixam lugar a dúvidas: Bocage, na fase final da sua breve existência, afirma-se a si mesmo como esse fantasma inexistente para além da treva. Mas um novo rosto preenche o que, entretanto, desce à "cova escura" e se desfaz - se fantasmagoriza. O corpo permanece silhueta perdida nas sombras do tempo. A sua imagem poética aproxima-o de um halo de claridade que só os grandes poetas podem ambicionar. Razão tinha o poeta sadino quando, com as palavras que em sua boca pôs José Jorge Letria, afirmou, em tom firme e emocionado:

Eu, já Bocage não sou, mas sobra de mim tudo o que mesmo doendo e fazendo sangrar me tornou grande e duradouro: o lume altaneiro da Poesia a lembrar a esta terra que só pode falar de eternidade quando molda o regaço para deixar dormir os seus poetas, mesmo que a inquietação os tenha feito náufragos sem porto nem abrigo, sempre em busca da palavra perdida, inominável, que acende a luz perene no coração dos séculos ${ }^{18}$.

17 Prado Coelho, J. 1966: 107.

18 José Jorge Letria (2002), Já Bocage Não Sou. Lisboa, Publicações Europa-América, 117. 


\section{Bibliografia}

Andrade, Miranda de (1966), "O poeta Manuel Maria Barbosa du Bocage”, Ocidente 70: 226-239.

CidAdE, Hernâni (1980), Bocage: a obra e o homem. Lisboa, Editora Arcádia.

CoElHo, Jacinto do Prado (Dezembro de 1965), "Bocage: a vocação do obscuro" in $O$ Tempo e o Modo 33: 1182-1194.

-, "Bocage: poeta do invisível" (1966), Memórias da Academia das Ciências de Lisboa, Classe de Letras 9: 101-121.

CostA, Eduardo Maia (1966), "Bocage - poeta iluminista”, Vértice 271-272: 3-15.

GonÇAlves, Adelto (2003), Bocage, o perfil perdido. Lisboa, Caminho.

LOPES, Óscar (1970), "Bocage - fronteiras de um individualismo”, Ler e Depois. Porto, Editorial Inova.

MAIA, João (Nov. 1965), "Bocage: o pré-romântico", in Brotéria 81: 500-508.

MoIsÉs, Carlos Filipe (1979), "Bocage e o século XVIII", in Colóquio Letras 50: 35-42.

MourÃo-Ferreira, David (1966), "O drama de Bocage”, in Hospital das Letras, Lisboa, Guimarães Editores: 57-62.

NEMÉSIO, Vitorino; MENDES, João; LEMOS, Esther de (1972), Gigantes da Literatura Universal - Bocage. Lisboa, Editorial Verbo.

PIRES, Daniel (2004-2005), "Introdução" à Obra Completa de Bocage. Porto, Edições Caixotim. 